\title{
Carrying capacity analysis of nature tourism activity in Selabintana, Gunung Gede Pangrango National Park, West Java
}

\author{
ANDRIYANTO SOFIYUDIN ${ }^{1}$, ROSADI $^{2}$, DOLLY PRIATNA ${ }^{2}$ \\ 'Balai Besar Taman Nasional Gunung Gede Pangrango, Jl. Raya Cibodas, Cianjur 43253, Indonesia \\ ${ }^{2}$ Graduate School of Environmental Management, Pakuan University, Jl. Pakuan, Bogor 16129, Indonesia
}

Corresponding author: andriys.smi@gmail.com

Submitted 28 July 2021; Accepted 26 August 2021

\begin{abstract}
Selabintana management area is one of the nature tourism areas in the Gunung Gede Pangrango National Park (GGPNP) which located in Sukabumi District, West Java. Within the management area which covers 2,547.93 ha, there is a camping ground and waterfall which both are the most attracted for visitors. Efforts are needed to harmonize nature tourism activities with conservation mission, so that visitors can enjoy but the natural environment is maintained. The objective of this research is to determine the carrying capacity for daily tourism and camping activities by considering the aspect of physical, environmental and management aspects. The survey conducted through interviews and questionnaires to 62 tourists, traders and managers of the national park area. The data were analyzed using the carrying capacity assessment method developed by Cifuentes, i.e. calculating the Physical Carrying Capacity (PCG), Real Carrying Capacity (RCG), and Effective Carrying Capacity (EGG). As a result, EEG for daily tourism is 84 visitors/day ( $\mathrm{PCG}>\mathrm{RCG}>\mathrm{EGC}$ with a score of 3,269 > 98 >84), while EEG for camping is 60 visitors/day $(\mathrm{PCG}>\mathrm{RGC}>$ with a score of 2,155>69 > 60). Thus, carrying capacity of nature tourism activities in conservation areas can be calculated based on physical carrying capacity, real carrying capacity, and effective carrying capacity.
\end{abstract}

\section{ABSTRAK}

Kawasan pengelolaan Selabintana merupakan salah satu areal wisata alam yang ada di Taman Nasional Gunung Gede Pangrango (TNGGP) yang terletak di Kabupaten Sukabumi, Jawa Barat. Di dalam areal pengelolaan yang luasnya 2.547,93 ha terdapat camping ground dan air terjun yang merupakan daya tarik utama yang bagi para pengunjung. Diperlukan adanya upaya untuk menyelarasakan kegiatan wisata alam dengan misi konservasi, agar pengunjung dapat menikmati namun lingkungan alam tetap terjaga. Tujuan dari penelitian ini adalah menentukan carrying capacity untuk kegiatan wisata harian dan berkemah dengan mempertimbangkan aspek fisik, lingkungan dan manajemen. Survey dilakukan melalui interview dan kuisioner terhadap 62 wisatawan, pedagang dan pengelola kawasan taman nasional. Data dianalisis dengan metode penilaian carrying capacity yang dikembangkan oleh Cifuentes, yaitu menghitung Daya Dukung Fisik (PCG), Daya Dukung Ril (RCG), serta Daya Dukung Efektif (ECG). Sebagai hasil, EEG untuk wisata harian adalah 84 pengunjung/hari $(\mathrm{PCC}>\mathrm{RCC}>\mathrm{ECC}$ dengan skor $3.269>98>84)$, sedangkan EEC untuk berkemah adalah 60 pengunjung/hari $(\mathrm{PCC}>\mathrm{RCC}>\mathrm{dengan}$ skor 2.155 $>69>60)$. Jadi, carrying capacity dalam kegiatan wisata alam di dalam kawasan konservasi dapat ditentukan berdasarkan daya dukung fisik, daya dukung riil, dan daya dukung efektif.

Keywords: carrying capacity, nature tourism, national park

\section{INTRODUGTION}

The involvement of stakeholders is a challenge in managing conservation areas such as national parks, so that an integrated management of national parks can be implemented. A such management model is currently needed considering the development of area zoning in the management strategy of a national park. One of the zone that has been being developed is the utilization zone. The type of utilization that has been widely developed in the management of national parks is the development of nature tourism businesses.

In the development of business-based nature tourism in a conservation area, various assessments are needed, especially those related to the carrying capacity of the environment. This is important to keep the conservation area sustainable, where the existing ecological system is maintained, the community can be involved, and there is an access to get the benefits of a national park.

Gunung Gede Pangrango National Park has been designated as the core zone of UNESCO's Biosphere Reserve Cibodas since 1997. In the concept of a biosphere reserve, the district's administrative area has been internationally recognized as part of an area managed through UNESCO's MAB (Man and the Biosphere) landscape approach in the context of conservation, scientific and humanity development programmes. The Selabintana management area in Sukabumi District is one of the natural tourist sites within the Gunung Gede Pangrango National Park which has been known as a location for ecotourism activities that attracts many visitors.

In 2018, the management of the national park has improved facilities and infrastructure to support tourism activities in Selabintana. With the addition of these facilities and infrastructure, it will certainly have a 
positive or negative impact on the development of natural tourism and environmental preservation. Therefore, we need a tourism management that can reduce negative impacts, which will cause damage to the environmental quality in the Selabintana management area.

In general, the determination of the carrying capacity of the environment and the carrying capacity of tourism aims to limit the use of a space or region. However, both have differences in their application. Physical carrying capacity or PGC is the maximum number of visitors that can be physically accommodated by the available space within a certain period of time. Real carrying capacity or $\mathrm{RCG}$ is the number of visitors who are allowed to visit a tourist attraction, with a correction factor $(\mathrm{CF})$ which is translated from the characteristics of the object applied to the physical carrying capacity. Effective carrying capacity or ECG is the maximum number of visits where the object will always be stable in its available management capacity or MC (Cifuentes, 1992; Khair, 2006; Sustri, 2009; Sayan \& Atik, 2011).

Based on various reasons above, it is necessary to have a formula that can be used in calculating the carrying capacity of natural tourism management, especially in a daily nature recreation areas and in campgrounds.

\section{METHODS}

This study was carried out in February-April 2021 in Selabintana management area of GGPNP, which covers an area of 2,547.93 ha. Administratively, it is located in Perbawati Village, Sukabumi District, West Java (Figure $1)$.

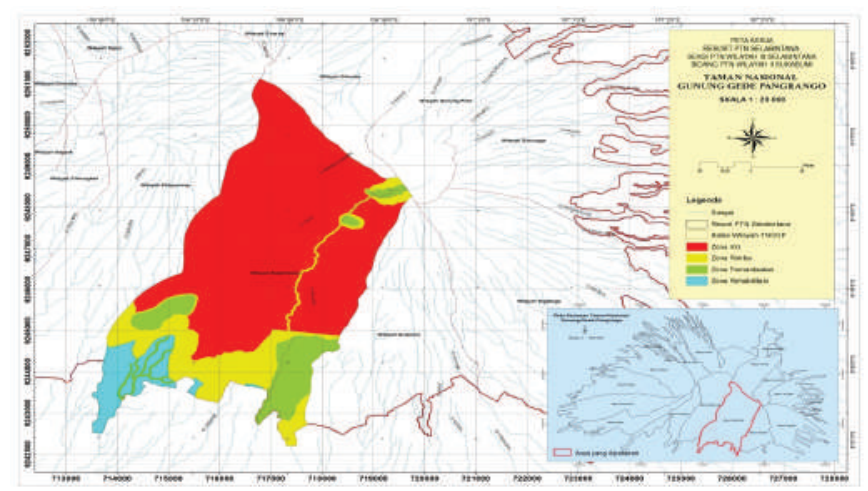

Figure 1. The map of study area in Selabintana management area of GGPNP, West Java.

In this study, there are two types of descriptive surveys, namely nature tourism activity in the waterfall area (daily tourism) and in the camping ground area in the utilization zone of the Selabintana management area. The scope of research on carrying capacity of nature tourism is limited to the definition of effective carrying capacity that developed by Cifuentes (1992). Data collection was carried out by two techniques, namely observation and interviews (using a questionnaires).

The survey was conducted on 62 respondents consisting of tourists or visitirs, tourism managers, and local traders who do business around the location. The direct observation technique is carried out to collect primary data, in the form of physical data (facilities and access, the length of the track in the tourist area), as well as observation and identification of the presence of trees and wildlife. Meanwhile, secondary data collected is data on tourism areas, road length, number of visitors, open period, wind speed, soil type, sunlight, and supporting data obtained from institutions. In the interview technique, the researcher met and deals directly with the respondent or the subject being studied. The data analysed using the following formula (Cifuentes, 1992):

$\mathrm{EGC}=\mathrm{RGC} \times \mathrm{MG}$

$M C=\frac{R_{n}}{R_{t}} \times 100 \%$

$\mathrm{R}_{\mathrm{n}}$ : number of available officers

$\mathrm{R}_{\mathrm{t}}$ : number of officers needed

$R C C=P C C \times \frac{100-C f 1}{100} \times \frac{100-C f 2}{100} \times \ldots . . \times \frac{100-C f n}{100}$

Where :

RCG (Real Carrying Capacity): maximum number of tourists allowed to visit by considering the factors of physical carrying capacity in the tourist area.

$C f_{n}=\frac{M_{n}}{M_{t}} \times 100 \%$

$\mathrm{Cf}_{\mathrm{n}}$ : the $\mathrm{n}^{\text {th }}$ reducing/correction factor associated with the $\mathrm{n}^{\text {th }}$ variable

$\mathrm{M}_{\mathrm{n}}$ : real condition on calculated $\mathrm{f}_{\mathrm{n}}$ variable

$\mathrm{M}_{\mathrm{t}}$ : maximum limit on $\mathrm{f}_{\mathrm{n}}$ variable

$P C C=A \times \frac{1}{B} \times R f$

Where :

PCC (Physical Carrying Capacity): maximum number of visitors that can be physically received in a tourist area at a given time (Fandeli \& Muhammad, 2009)

A: size of tourism area

B: size of area required by a tourist while still obtaining satisfaction.

Rf: rotation factor or number of repeat visits per day.

\section{RESULTS AND DISGUSSION}

\section{Carrying Capacity of Nature Tourism}

Daily tourism activity in Selabintana operates between 07:30 to $16: 00$ (8.5 hours per day), while the result of interview with the tourists/visitors, show that the average of their spending time is 4 hours to do tourism activity 
within the area of Selabintana. Then, the rotation factor or number of repeat visits per day (Rf) is 2.13. Thus, the maximum number of visitors that can be physically received in a tourist area at a given time $(\mathrm{PCG})$ in this area is 3,792 visitors/day (rounded from 3,792.13).

For the camping activity in camping ground of Selabintana, park manager has provided 24 hours, but the average duration of camping activity that spent by visitors is 16 hours, with Rotation factor $(\mathrm{Rf})$ is 1.5 . Thus, the PCG for camping activity is 2,155 visitors/day (rounded from 2,155.1).

\section{Real Garrying Gapacity (RGG)}

The study of the relevant correction factors for the natural characteristics is needed to conduct an RCG analysis. In Selabintana region, there are several correction factors, i.e. rainfall, landscape, soil erosion, slope, and biodiversity index.

\section{Rainfall correction factor}

Secondary data about the number of rain days in the last 5 years compared to the number of visit days. The number of rain days in the past 5 years is 781 days, and the number of visit days is 1,736 days. Then the rainfall index is $44.99 \%$ or index 0.45 .

\section{Landscape correction factor}

The calculation is obtained based on weight assessment of the respondents on the terrain characteristics, vegetation, scenery, colours of view, and infrastructure. Survey is conducted using assessment instruments.

\section{Erosion correction factor}

Based on secondary data (Java and Madura soil maps) the type of soil in Selabintana management area is latosol soil type (30 points) and andosol (60 points) and Mt (75 points).

$\mathrm{M} 1=(30+60) / 2$

$\mathrm{M} 1=45$

$\mathrm{Cfe}=45 / 75 \times 100 \%$

$\mathrm{Cfe}=60 \%=0.60$

Thus, the potential index of soil erosion sensitivity is 0.6

\section{Slope correction factor}

The assessment was carried out by using a score on the criteria for the slope class on visitor route with a slope level score of 0-100.

$\mathrm{Cfs}=46,66 / 100 \times 100 \%$

$\mathrm{Cfs}=46.66 \%=0.47$

Correction factor for daily visitor slope index is $46.66 \%$ or 0.47 .

Correction factor for camping slope index is $34.28 \%$ or 0.34 .

\section{Biodiversity correction factor}

Simpson's diversity index was employed to measuring the level of tree vegetation and birds (Cfd) or (Gf5). In the analysis of vegetation obtained 321 trees of 32 species. Thus, tree diversity index is 0.510 and the total number of variables for the index $(\mathrm{Mt})$ is 1 . Therefore, the calculation of correction factor for tree diversity is as follows:

Cftr $=0.510 / 1 \times 100 \%$
Cftr $=51 \%=0.51$

The result of bird diversity index assessment within tourism area was obtained 218 individuals of birds from 32 species.

Cfbr $=2.61 / 3.5 \times 100 \%$
Cfbr $=74.57 \%=0.75$

For obtaining the correction factor of diversity (which was generated from tree vegetation diversity and bird diversity indexes)can be calculated as follows:

$$
\begin{aligned}
& \text { Cfd }=(\text { Cftr }+ \text { Cfbr }) / 2 \\
& \text { Cfd }=(51 \%+74.57 \%) / 2 \\
& \text { Cfd }=62.78 \%=0.63
\end{aligned}
$$

Based on the index assessment of each correction factor, then the RCG value for daily tourism and camping in Selabintana management area can be calculated as follows:

Real Carrying Capacity (RGG) of daily tourism in Selabintana:

$\mathrm{RCC}=3,269 \times 0.55 \times 0.59 \times 0.40 \times 0.53 \times 0.37=98.17$ Thus, the RGC value for daily tourism is 98 visitors/day (rounded from 98.17).

Real Carrying Capacity (RCG) of camping in Selabintana:

$\mathrm{RCC}=2,155 \times 0.55 \times 0.59 \times 0.40 \times 0.66 \times 0.37=68,73$ Thus, the RCG value for camping is 69 visitors/day (rounded from 68.73).

\section{Garrying Capacity of Nature Tourism}

Selabintana management area has 8 (eight) staff, but in carrying out their duties every day there are only 7 (seven) staff working because there is always 1 (one) person takes a day off. Thus, the value of management capacity (MC) can be calculated with the following equation:

Effective Carrying Capacity (ECG) for daily tourism:

$\mathrm{EGC}=\mathrm{PGC} \times \mathrm{MG}$

$\mathrm{ECC}=98 \times 0.875$

$\mathrm{ECC}=84.14$ 
Thus, the value of ECC for daily tourism in Selabintana management area is 84 person/day (rounded from 84.14).

Effective Carrying Capacity (ECG) for camping:

$\mathrm{ECG}=\mathrm{PCC} \times \mathrm{MC}$

$\mathrm{ECC}=69 \times 0.875$

$\mathrm{ECC}=60.14$

Thus, the value of ECG for camping in Selabintana management area is 60 person/day (rounded from $60.14)$.

Based on calculation result of daily tourism, we will know the value of Physical Carrying capacity (PGG), Real Carrying Capacity (RCG) and the Effective Carrying Capacity (ECG). Therefore, the equation obtained is $\mathrm{PGC}>\mathrm{RGC}>\mathrm{EGC}$ with value of 3,269 > $98>84$. From the calculation result data, the visitors of daily tourism that can be physically accommodated is 3,269 visitors per day. Afterwards, with the presence of correction factor that affects space and nature tourism activity is 98 visitors per day. Thus, the maximum number of visitor that can be accommodated by Selabintana management area with its correction factor and considering its management capacity is 84 visitors per day.

The result of calculation for the camping activity, shows the value of Physical Carrying Capacity (PCG), Real Carrying Capacity (RCG) and Effective Carrying Capacity (ECG), then the equation obtained is $\mathrm{PCG}>$ $\mathrm{RCG}>\mathrm{EGC}$ with value of $2.155>69>60$. From the calculation result, the visitors that can be physically accommodated is 2,155 visitors per day. Then, with the presence of correction factor that affects space and nature tourism activity is 69 visitors per day. Thus, the maximum number that could be accommodated by Selabintana management area with its correction factor and considering its management capacity is as many as 60 people per day.

\section{GONGLUSION}

A nature tourism area as one of the objects in conservation area (such as national park) management could be assessed through Physical Carrying Capacity (PCG). However, the capacity would turn into Real Carrying Capacity (RCG) through the study of natural factors correction. Those correction factors are the natural physical level, the ecology aspects preservation, and the vulnerability level of disaster. The final determination is Effective Carrying Capacity as the response of Management Capacity (MC) towards Real Carrying Capacity.

For the daily tourism and camping in Selabintana of Gunung Gede Pangrango National Park indicates the $\mathrm{PGC}>\mathrm{RGC}>\mathrm{EGG}$ value, which means based on the opening of Selabintana natural tourism could be applied in accordance with that equation.

\section{REFERENCE}

Budiani, S.R., Puspitasari, L., Adibah, M.N., Fauzia,A. \& Basuki S.N. 2019. Kajian daya dukung fisik wisata berkemah Telaga Cebong Desa Sembungan untuk mendukung pariwisata berkelanjutan. Majalah Geografi Indonesia, 33 (1): 9-15.

Cahyani. F.A. 2019. Upaya peningkatan daya dukung lingkungan hidup melalui instrumen pencegahan kerusakan lingkungan hidup berdasarkan Undang-Undang No.32 Tahun 2009 tentang Perlindungan dan Pengelolaan Lingkungan Hudup. fournal Ilmu Hukum, 2 (1): 53-60.

Ceballos, L.H. 1996. Tourism, Ecotourism, and Protected Areas. IUCN Protected Areas Programme, IUGN.

Cifuentes, M.A. 1992. Determination Carrying capacity of Tourism in Protected Area. CTIE Papers. Turrialba, Costa Rica. pp. 1-19.

Cifuentes, M.A. 1999. Tourist Carrying capacity in public use areas Guayabo National Monument, Costa Rica.

Fandeli, C. 2000. Perencanaan Kepariwisataan Alam. Kursus Pengusahaan Ekowisata. Fakultas Kehutanan Universitas Gajah Mada, Yogyakarta.

Fandeli, C. 2002. Perencanaan Wisata Alam. Fakultas Kehutanan Universitas Gadjah Mada, Yogyakarta.

Fandeli, C. dan Muhammad. 2009. Prinsip Dasar Mengkonservasi Lanskap. Universitas Gajah Mada, Yogyakarta.

Fandeli, C. \& Suyanto, A. 1999. Kajian daya dukung lingkungan, objek dan daya tarik Taman Grojogan Sewu, Tawangmangu. Furnal Manusia dan Lingkungan, 19 (VII): 32-47.

Fandeli, C. \& Nurdin, M. 2005. Pengembangan ekowisata berbasis konservasi di Taman Nasional. Pusat Studi Pariwisata Universitas Gadjah Mada dan Kantor Kementerian Lingkungan Hidup, Yogyakarta.

Jaringan Ekowisata Indonesia (Indecon). 1999. Pelestarian Ekosistem Leuser dan Peningkatan Ekonomi Masyarakat melalui Pengembangan Ekowissata. Makalah Pelatihan Ekowisata. Pp. 1-5.

Khair, U. 2006. Daya Dukung Fisik Ekowisata di Taman Wisata Alam Sibolangit, Deli Serdang. Tesis. Sekolah Pascasarjana Universitas Sumatera Utara, Medan.

Muta'ali, L. 2012. Environmental Carrying capacity for Regional Development Planning. Faculty of Geography, Gadjah Mada University, Yogyakarta.

Siswantoro, H. 2012. Kajian Daya Dukung Lingkungan Taman Wisata Alam Grojogan Sewu, Karanganyar. Tesis. Universitas Diponogoro, Semarang. 
Undang-Undang Republik Indonesia No. 5 Tahun 1990 tentang Konservasi Sumber Daya Alam dan Ekosistem Republik Indonesia.

Undang Undang Republik Indonesia No 32 tahun 2009 tentang Perlindungan dan Pengelolaan Lingkungan Hidup.
Undang-Undang Republik Indonesia Nomor 9 Tahun 1990 tentang Kepariwisataan Republik Indonesia.)

Zerlina, D., Dewi, I,K. \& Sutanto. 2019. Feasibility analysis of lake ex-andesite stone mining as geo-tourism area at Tegalega Village, Cigudeg, Bogor. Indonesian Journal of Applied Environmental Studies, 1(1): 40-47. 